\title{
Effect of Particle Pre-Treatment on Properties of Jatropha Fruit Hulls Particleboard ${ }^{1}$
}

\author{
Apri Heri Iswanto $\mathbb{D}^{2, \dagger} \cdot$ Fauzi Febrianto ${ }^{3} \cdot$ Yusuf Sudo Hadi ${ }^{3} \cdot$ Surdiding Ruhendi $^{3} \cdot$ \\ Dede Hermawan $^{3} \cdot$ Widya Fatriasari ${ }^{4}$
}

\begin{abstract}
The objective of the research was to evaluate the effect of particle pre-treatment on physical, mechanical, and durability of jatropha fruit hulls (JFH) particleboard. The pre-treatments included were immersing in cold water, hot water, and acetic acid solution. After each treatment, the particles were dried up to 3\% moisture content. Urea-formaldehyde (UF) resin was used to fabricate particleboards with board size, thickness and density target of $25 \mathrm{~cm} \mathrm{by} 25 \mathrm{~cm}, 0.80 \mathrm{~cm}$, and $0.70 \mathrm{~g} / \mathrm{cm}^{3}$, respectively. Board pressed at $130{ }^{\circ} \mathrm{C}$ for 10 minutes, and $25 \mathrm{~kg} / \mathrm{cm}^{2}$ pressure. The evaluation of particleboard followed the JIS A 5908-2003. Whilist their resistance to subterranean termite test (mass loss, mortality, antifeedant value and feeding rate) refers to the Indonesian standard (SNI 01.7207-2006). The physical and mechanical properties of particleboards showed that all pre-treatments decreased the $\mathrm{pH}$ of particles. Overall, all particle immersing treatments resulted of better physical and mechanical properties of particleboard than those of untreated ones. The acetic acid treatment resulted the best physical and mechanical properties of particleboard. Based on the mass loss of JFH particleboard, hot water and acetic acid treated particleboards were classified into weak resistance to subterranean attack. The other two treatments were classified into very weak resistance. Hot water treated particleboard provided the highest mortality and antifeedant as much as $87.40 \%$ and $34.20 \%$, respectively. Based on antifeedant classification, hot water treated particleboards were classified into moderately strong resistance, while other treatments were categorized into weak resistance. The lowest feeding rate value $(45.30 \mu \mathrm{g} /$ termite/day $)$ was attained by hot water treatment.
\end{abstract}

Keywords: JFH pre-treatment, $\mathrm{pH}$, physical-mechanical, durability

\section{INTRODUCTION}

Jatropha curcas is one of the important sources for biodiesel. It grows in various land condition and across different climate zones. Biodiesel process using this material can produce the fibrous fruit hulls as waste.
Sudradjat et al. (2005) reported that Jatropha fruit consists of seeds meat (40\%), seed coat $(13 \%)$, and fruit hulls or fiber $(47 \%)$ based on dried weight. Considering the preliminary observation on the chemical properties (cellulose, hemicellulose, and lignin content), Jatropha fruit hulls are promising materials for particleboard.

\footnotetext{
${ }^{1}$ Date Received January 4, 2018, Date Accepted March 12, 2018

${ }^{2}$ Department of Forest Product, Faculty of Forestry, Universitas Sumatera Utara, Padang Bulan, Medan 20155, Indonesia

${ }^{3}$ Department of Forest Products, Faculty of Forestry, Bogor Agricultural University, Bogor-Indonesia

${ }^{4}$ Research Center for Biomaterials LIPI, Bogor-Indonesia

$\dagger$ Corresponding author: Apri Heri Iswanto(e-mail: apriheri@yahoo.com, ORCID: 0000-0002-4243-1429)
} 
Apri Heri Iswanto $\cdot$ Fauzi Febrianto $\cdot$ Yusuf Sudo Hadi $\cdot$ Surdiding Ruhendi $\cdot$ Dede Hermawan $\cdot$ Widya Fatriasari

Its cellulose, hemicellulose, and lignin content were $48.6 \%, 7.99 \%$, and $21.45 \%$, respectively.

The preliminary research showed that the $\mathrm{pH}$ of $\mathrm{JFH}$ was 10. About 45 type of JFH chemical compounds of pyrolisis gas chromatograph-mass spectrometer (PGC-MS) likely has alkaline components, including ammonium bicarbonate, mercaptomethane, guaiacol, 2,6-dimethoxyphenol and cyclopropyl carbinol. The blending of JFH with UF resin for the manufacturing of particleboard will cause curing problem and as result its board quality will be deteriorated. Paridah et al. (2001) stated that the rate of resin polymerization depended on wood and adhesive condition. The materials are important factor for hot-pressing parameter such as temperature and time. To obtain optimum bond strength, the pressing condition should be controlled by (1) adjusting of time and temperature, and (2) adjusting the acidity level of materials for a specific adhesives to be used.

JFH pre-treatment (i.e immersing in cold water, hot water, and acetic acid solution) is expected to decrease the $\mathrm{pH}$ level of JFH. An acidic condition will accelerate the curing of UF resins. In biocomposite manufacturing, each material must have specific $\mathrm{pH}$ range to obtain optimum bonding strength for a specific resin adheisve. Thus, considering $\mathrm{pH}$ and buffering capacity of wood have strong effect on curing time and bonding strength of adhesives (Colak et al., 2006; Park et al., 2001; Zanetti and Pizzi, 2003). Freeman (1959) found that increasing of wood $\mathrm{pH}$ caused weakening of UF resin bonding, reducing polymerization rate, and lowering of wood- adhesive bonding as well. In addition, a strong relationship between gelatin time of UF and $\mathrm{pH}$ was reported before, while gelatin time and acid buffering capacity from wood extract had an opposite relationship was reported. Xing et al. (2004) reported that wood $\mathrm{pH}$ had strong influence on the gelatin time at lower catalyst concentration, and it decreased with an increase in the catalyst concentration.
JFH has low durability indicated by its high extractive content in $\mathrm{NaOH}$ solubility as much as $35.1 \%$. Furthermore, Jasni and Sulastiningsih (2004) reported that the particleboard from low durable materials had a low resistance against to termite attack. Therefore, durability improvement for JFH particleboard is needed. Improvement of particleboard durability to termite attack can be conducted through pre- or post-treatment. Iswanto et al. (2010) reported that pre-treatment to strand such as immersing in cold water for 24 hour, hot water for 1 hour and preservative solution $(2.5 \%$ chrom copper boron) had increased the durability of oriented strand board (OSB) against to subterranean termite attack. Besides, Hadi (1991) reported that 7\% weight percent gain (WPG) and 18\% WPG of acetylation treatment on flakeboard from rubber wood resulted in lower weight loss value compared to those of the untreated wood flakes. Weight loss values of 7\% WPG and $18 \%$ WPG treatment were $57.1 \%$ and $8.65 \%$, respectively, while untreated one was $83.6 \%$. In addition, the post- treatment using alkaline copper quat (ACQ) and copper azole (CA) for wood-based composites (softwood and hardwood plywood, medium density fiberboard, OSB, and particleboard) improved the resistance to termite attack (Tascioglu et al. 2013). Thus, in order to improve the physical and mechanical properties of JFH particleboard, particle pre-treatment is also expected to increase the durability of particleboard. The objective of the research was to evaluate the effect of pre-treatment methods on physical, mechanical, and durability properties of JFH particleboard.

\section{MATERIALS and METHODS}

\subsection{Materials}

JFH as biodiesel waste was collected from biodiesel industry. The particle and its size was displayed in Fig. 1 and Table 1. Commercial UF resin (Type UA-140 
Table 1. Size and slenderness ratio of Jatropha fruit hulls ${ }^{(\mathrm{n})}$

\begin{tabular}{lccc}
\hline Parameter & Average & Min & Max \\
\hline \hline Length (mm) & $27.46 \pm 1.41$ & 24.00 & 30.00 \\
Width (mm) & $1.51 \pm 0.14$ & 1.15 & 1.84 \\
Thickness (mm) & $0.34 \pm 0.13$ & 0.10 & 0.70 \\
Slenderness Ratio (SR) & $92.35 \pm 33.58$ & 41.43 & 260.00 \\
Aspect Ratio (AR) & $4.96 \pm 1.97$ & 16.57 & 2.20 \\
\hline
\end{tabular}

(n): 100 samples

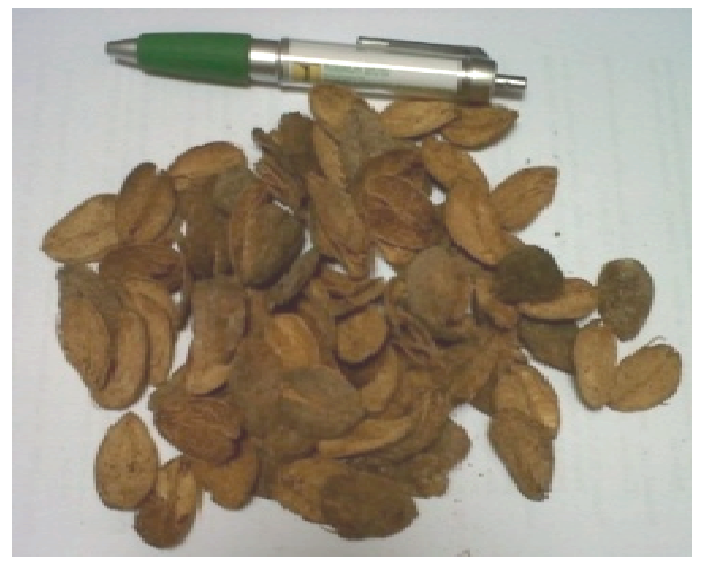

Fig. 1. Jatropha fruit hulls.

for particleboard manufacturing) as much as $10 \%$ based on oven dry (OD) mass of particle was used as an adhesive. About $1 \%(\% \mathrm{v} / \mathrm{v})$ acetic acid solution was used for JFH particle treatment. The moisture content of particles was $3 \%$.

\subsection{Methods}

\subsubsection{Particle Treatments}

JFH particles were soaked in cold water for 24 hours at $25^{\circ} \mathrm{C}$, in hot water at $80^{\circ} \mathrm{C}$ for 1 hour, and in $1 \%$ acetic acid solution for 24 hours at $25^{\circ} \mathrm{C}$. Then, the particles were oven dried to reach of $3 \%$ moisture content. To observe treatment effect, untreated particles were also prepared as comparison.

\subsubsection{Particle Analysis}

2.2.2.1. Determination of extractive contents in hot water extraction and $1 \% \mathrm{NaOH}$

After pre-treatment, the determination of extractive content was conducted by in hot water extraction and $1 \% \mathrm{NaOH}$ solution followed the procedure of TAPPI 1 os-50 (1950) and TAPPI 1 os-59 (1959), respectively.

2.2.2.2. Determination of $\mathrm{pH}$ and buffering capacity of JFH particles

The buffering capacity and $\mathrm{pH}$ of treated particles was also measured. The buffering capacity of JFH particles was determined by the method of Krilov and Lasander (1998). Afterward, the pHs of extracted JFH particles were determined according to Johns and Niazi (1980).

\subsubsection{FTIR Analysis}

Amount of $2 \mathrm{mg}$ sample was mixed with $\mathrm{KBr}(0.4$ g) powder to make a pellet for FTIR (Shimadzu FTIR-8400) analysis. All spectra were recorded at $24^{\circ} \mathrm{C}$. This procedure provided FTIR spectra data less than $2 \%$ deviation.

\subsubsection{Particleboard Manufacturing}

Single layer JFH particleboards were produced with the size, targeted thickness and density of $25 \mathrm{~cm}$ by $25 \mathrm{~cm}, 0.8 \mathrm{~cm}$ and $0.70 \mathrm{~g} / \mathrm{cm}^{3}$, respectively. About 
Apri Heri Iswanto $\cdot$ Fauzi Febrianto $\cdot$ Yusuf Sudo Hadi $\cdot$ Surdiding Ruhendi $\cdot$ Dede Hermawan $\cdot$ Widya Fatriasari

$10 \%$ UF resin with $63 \%$ solid content was used as a binder for the particleboard. Blending particles with adhesive was conducted in a rotary drum blender. Furthermore, the mats were hot pressed at $130^{\circ} \mathrm{C}$ under $25 \mathrm{~kg} / \mathrm{cm}^{2}$ for 10 minute, and then boards were conditioned at room temperature for seven days. The replication of each treatment was triplicates.

\subsubsection{Particleboard Evaluation}

2.2.4.1. Determination of physical-mechanical and durability properties

The physical properties measured were air-dry density, moisture content (MC), water absorption (WA), thickness swelling (TS), while mechanical properties determiend were modulus of rupture (MOR), modulus of elasticity (MOE), and internal bond (IB) according to JIS A 5908 (2003).

\subsubsection{Determination of Durability to Subterranean Termite Attack}

Durability test refers to the Indonesian National Standard (SNI) 01.7207-2006 (Indonesian National Standard, 2006). Specimens with length and width of 2.5 by $2.5 \mathrm{~cm}$ were dried at $103^{\circ} \mathrm{C}$ up to constant weight. After that samples were burried in the round jam pot (450 to $500 \mathrm{~mL}$ volume, with a wide-mouth and a bottom area of 25 to $30 \mathrm{~cm}^{2}$ ) which were filled with $200 \mathrm{~g}$ of $7 \% \mathrm{MC}$ sand below to water holding capacity. As amount of 200 subterranean termites (Coptotermes curvignathus Holmgren) were put in the jam pots, and then they were placed in a dark room for four weeks at room temperature. At the end of the test, mass loss, mortality, antifeedant and feeding rate value of specimen was determined. Durability of JFH particleboard clasification based on its weight loss is presented in Table 2. Durability classification based on antifeedant value is presented in Table 3.
Table 2. Classification of wood resistance to subterranean termite based on mass loss (Indonesian National Standard, 2006)

\begin{tabular}{clc}
\hline Class & Resistance rate & Mass loss $(\%)$ \\
\hline \hline I & Very Resistance & $<3.52$ \\
II & Resistance & 3.52 to 7.50 \\
III & Moderately strong & 7.50 to 10.96 \\
IV & Weak & 10.96 to 18.94 \\
V & Very weak & 18.94 to 31.89 \\
\hline
\end{tabular}

Table 3. Classification of wood resistance to subterranean termite based on antifeedant value (Sornnuwats et al.1995)

\begin{tabular}{ccl}
\hline Class & Antifeedant value $(\%)$ & Resistance Rate \\
\hline \hline IV & $75 \leq \mathrm{x}<100$ & very strong \\
III & $50 \leq \mathrm{x}<75$ & strong \\
II & $25 \leq \mathrm{x}<50$ & moderately strong \\
I & $0 \leq \mathrm{x}<25$ & Weak \\
\hline
\end{tabular}

\section{RESULTS and DISCUSSION}

\subsection{Particle Analysis}

\subsubsection{Extractive Content, and $\mathrm{pH}$ of JFH Particles}

Overall, immersing treatment of JFH particle decreased $\mathrm{pH}$, extractive content (Fig. 2). Extractive content will reduce the permeability and inhibit the adhesive penetration in the wood cell. According to Sernek (2002), wood extractives can affect wood wettability and adhesive spread on the particles. Most extractives are water-repellent and hydrophobic characteristic. When the hot pressing process, extractive will come out from the particle. It will affect the gluing process. Christiansen (1990) reported that hot-pressing time and temperature will change the wettability of wood. This condition facilitates the extractive migration on the wood surface. After heating treatment of wood, extractive substances come out on the wood surface, which 


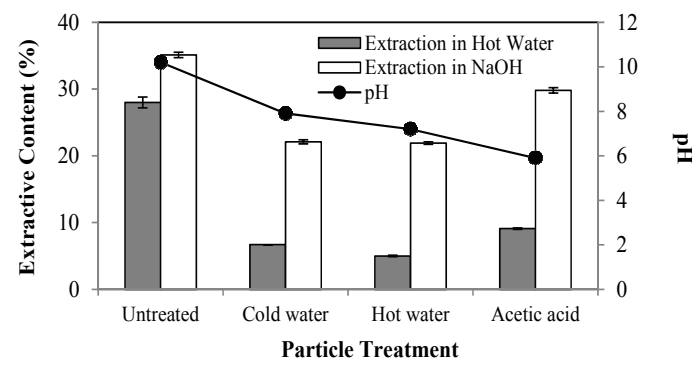

Fig. 2. Extractive content and $\mathrm{pH}$ of the JFH at different pre-treatments.

will cause to poor wettability and adhesion through the surface inactivation (Podgorski et al. 2000).

In the previous study was reported that several treatments such as particle immersing in hot and cold water, and using steam treatment had been conducted (Iswanto et al., 2010; Maulana et al., 2017); and Febrianto et al., 2009). This research focused on reducing of extractive content and $\mathrm{pH}$ through to be immersing of JFH particle in cold water, hot water, and acetic acid solution. These conditions were expected to make JFH particles more suitable to UF resin adhesive because UF resin had a fater cure in acidic conditions. According to Kamal et al. (2010), the acidity level of materials is an important factor in producing particleboard using both acid-curing UF resin and alkalinecuring PF resin adhesives. These conditions also affect to determine temperature and time duration of hot pressing in order to obtain optimal curing condition. The rate of polymerization of the adhesive will increase or decrease depending on the raw material types i.e. wood and adhesives.

Immersing treatment of JFH particles in both cold water and acetic acid solution causes a decrease in the $\mathrm{pH}$ value compared to that of the untreated sample. As shown in Fig. 3, FTIR spectra showed $1650.94 \mathrm{~cm}^{-1}$, which was responsible for the $\mathrm{C}=\mathrm{O}$ stretch depitched acid groups. And this absorbance of pre-treated samples is higher compared to untreated ones. This result suggest that the pre-treatment caused an increase in the func-

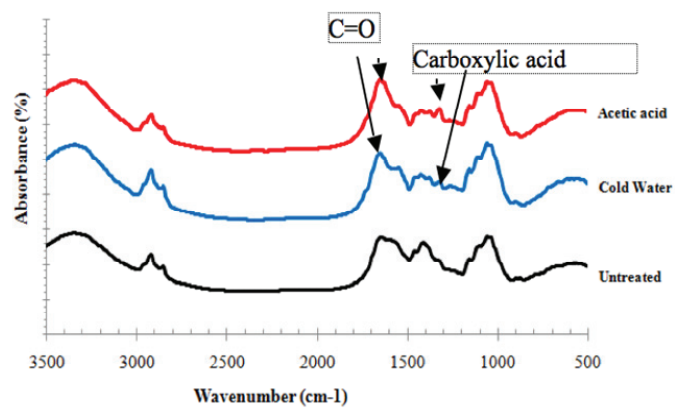

Fig. 3. FTIR spectra of untreated and pretreated JFH particles.

tional group of JFH acid compound constituents, such as acetic acid, isopropenyl acetate and methyl acetate. In addition, the wavenumber of $1326.93 \mathrm{~cm}^{-1}$ represents the $\mathrm{C}=\mathrm{O}$ stretching or $\mathrm{O}-\mathrm{H}$ bending identified as aliphatic acid groups. A new peak of pre-treated samples found in this area indicates the formation of carboxylic acid groups. According to Sujadi (1985), the band at wavenumber of 1,800 to $1,600 \mathrm{~cm}^{-1}$ and $1,400 \sim 1,200$ $\mathrm{cm}^{-1}$ indicated the presence of the carboxylic acid compound and its salt.

\subsection{Board Evaluation}

\subsubsection{Physical and Mechanical Properties of Particleboard}

\subsubsection{Density and Moisture Content of JFH Particleboard}

The density and moisture content of JFH particleboard were shown in Fig. 4. The density and MC of JFH particleboard were ranged from 0.64 to $0.69 \mathrm{~g} / \mathrm{cm}^{3}$ and 7.41 to $8.48 \%$, respectively. The lowest and highest density values were found for particleboards whose particles had been immersed in hot water and untreated particles, respectively. All board densities are lower than the target density of $0.70 \mathrm{~g} / \mathrm{cm}^{3}$. Kelly (1977) reported particleboard density has been influenced by wood species, pressure level during hot-press, particle quantity, resin content, and additives. 
Apri Heri Iswanto $\cdot$ Fauzi Febrianto $\cdot$ Yusuf Sudo Hadi $\cdot$ Surdiding Ruhendi $\cdot$ Dede Hermawan $\cdot$ Widya Fatriasari

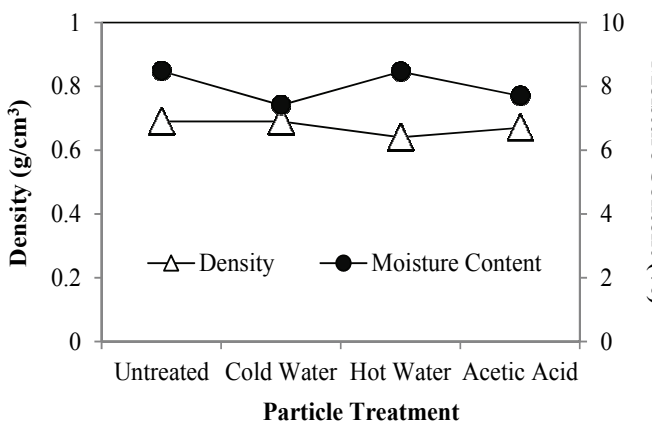

Fig. 4. Density and moisture content of particleboard.

Treated particleboards showed lower MC than that of untreated ones. Immersing treatment reduced the $\mathrm{pH}$ of JFH (Fig. 4). This condition makes UF resin will bind easier and accelerate the polymerization in acidic condition. As displayed in Fig. 3 (FTIR analysis), the absorbance bands of $3340.46 \mathrm{~cm}^{-1}$ assigned as $\mathrm{O}-\mathrm{H}$ groups increased in the pre-treated sample. The presence acid groups of acetic acid pre-treated samples at wavenumber of $1650.94 \mathrm{~cm}^{-1}$ contributes it. An increase in the acidic group will obiously acclerate the cure of UF resins.

The lowest and highest MC were found for particleboards whose their particles had been immersed in cold water and untreated ones, respectively. Particle immersion treatment will increase resin penetration in the cell wall and results of low in water accessibility. Harmsen et al. (2010) reported that chemical mod-

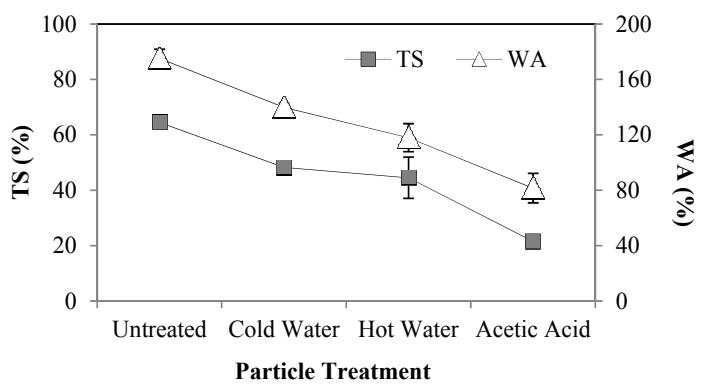

Fig. 5. Water absorption and thickness swelling of particleboard. ification treatment by weak acid will cause hemicellulose hydrolysis, it will decrease hydrophilicity, and increase hydrophobicity of wood cell walls. And it will also increase porosity of wood cell walls which will improve the resin penentration for adhesive bonding. The analysis of variance showed that particle pre-treatment had no significant effect on the density and MC of particleboard.

\subsubsection{Water Absorption and Thickness Swelling of JFH Particleboard}

The water absorption and thickness swelling value were varied from 81.5 to $175.2 \%$, and from 21.5 to $64.5 \%$, respectively (Fig. 5). Whilst the lowest and highest WA and TS value were obtained on particleboard whose particles had been immersed in acetic solution and untreated particles, respectively. Immersing treatments decreased the WA and TS compared to those of untreated boards. It was presumably due to some extractive substances that had been removed during particle pre-treatment. In general, a high TS is related to low internal bond (IB) strength value. This was supported by the negative correlation between TS and IB (Fig. 6).

Particle pre-treatment improved WA and TS value of particleboard. It can attributed to a decrease in the particle acidity $(\mathrm{pH})$ to accelerate the polymerization reaction of UF resin under acidic condition. Riedl

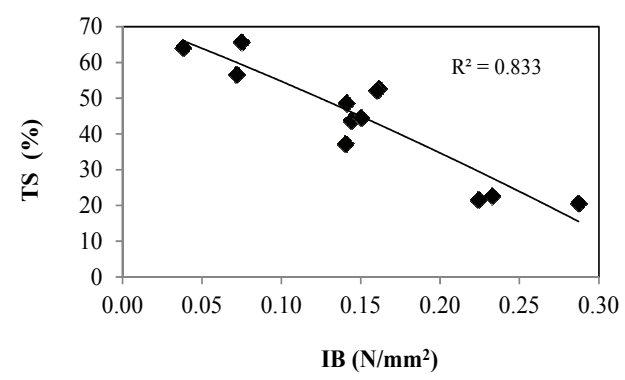

Fig. 6. The relation between of thickness swelling (TS) and internal bond (IB). 
(2004) reported that in acid condition, etherification had occured between cellulose and formaldehyde from UF resin. Furthermore, the hydroxymethyl group of UF resins would be working reactively in acid and hot condition, and then activating urea oligomers to form bismethylene ether or ethylene bridge. The analysis of variance showed that particle pre-treatment was highly significant effect to WA and TS value.

\subsubsection{MOR, MOE and IB strength of JFH Particleboard}

Modulus of elasticity and modulus of rupture value were around 462.18 to $1006.52 \mathrm{~N} / \mathrm{mm}^{2}$, and 3.38 to $10.65 \mathrm{~N} / \mathrm{mm}^{2}$, respectively (Fig. 7). The lowest and highest MOE and MOR values were found for particleboards that had been prepared with particles of untreated and acetic acid treatment, respectively. Overall, treated particleboards result in a better mechanical properties compared to untreated board. A higher MOE and MOR value was found for treated board. This treatment decreased the acidity $(\mathrm{pH})$ from 10.2 of untreated particles to 7 8 for particles immersed in hot and cold water and less than 6 for particles immersed in acetic acid solution. Particles with acidic $\mathrm{pH}$ has more suitable to faciliate the curing of UF resin for obtaining better performance in bonding quality (Pan et al. 2007). Acetic acid immersion treatment of particles is selected as the best treatment to improve mechanical properties of particleboard, eventhough its

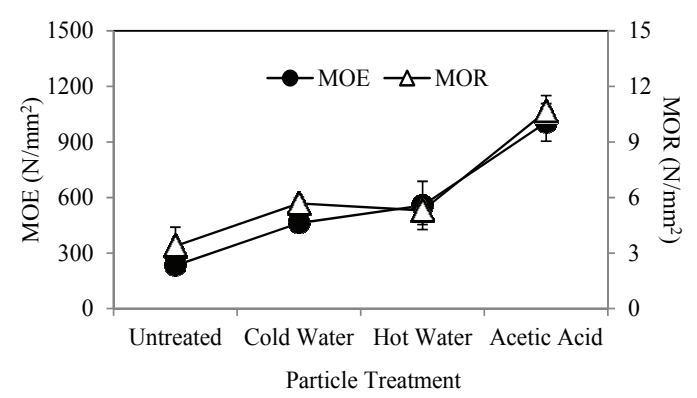

Fig. 7. MOE and MOR of particleboard.
MOE value is not satisfied the requirement of the standard (JIS A 5908, 2003). Maloney (1993) reported that MOE value was influenced by bonding strength of resin, fiber length of particle, resin type as well as its content. The analysis of variance showed that particle pre-treatment was highly significant effect on MOE and MOR.

The average value of IB strength ranged between 0.06 to $0.25 \mathrm{~N} / \mathrm{mm}^{2}$. The lowest and highest IB values were obtained at particleboards prepared by untreated particles and those by acetic acid immersion treatment and, respectively. Han (2009) stated that the extraction of non-wood materials significantly increased $\mathrm{pH}$. For UF resins, high $\mathrm{pH}$ will increase the gelation time, and then it will decrease bond strength. Particle immersion in acetic acid solution was choosen as the best treatment to increase IB strength of board. A low IB strength value of particleboard is affected by high $\mathrm{pH}$ (10.2) of JFH particle, which will retard the curing of UF resins. Particle acidity is one of factor affecting IB value, this statement supported by Park et al. (2001). He stated that internal bond of MDF bonded with UF can be affected by fiber acidity. Furthermore, Malanit et al. (2009) reported that the curing time of UF resin and bonding strength would increase or decrease, respectively, depeding on the $\mathrm{pH}$ and buffering capacity of particles. In addition, the catalyst addition level is also playing an important role in the curing of UF resins. Materials which have high acidity need catalyst

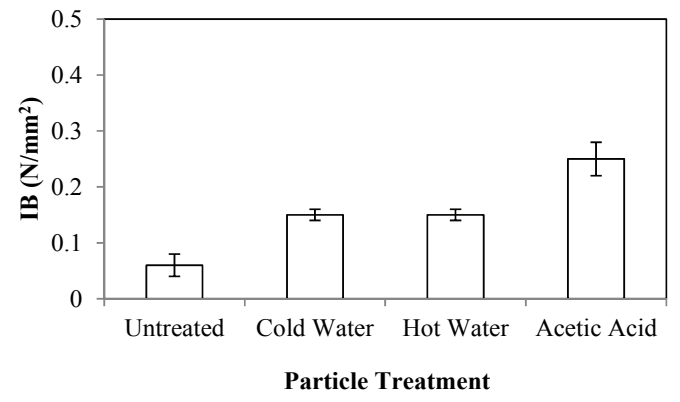

Fig. 8. Internal bond properties of particleboard. 
Apri Heri Iswanto $\cdot$ Fauzi Febrianto $\cdot$ Yusuf Sudo Hadi $\cdot$ Surdiding Ruhendi $\cdot$ Dede Hermawan $\cdot$ Widya Fatriasari

addition for resin curing to produce of particleboard bonded with UF resin. Iswanto et al (2017) reported that Sengon particles of lower $\mathrm{pH}$ provided higher IB strength of partilcleboard than those of Mahogany particles when UF resins were used as adhesives. Another factor affecting IB strength is high extractive content of JFH, which could interfere the adhesive penetration into wood particles.

\subsubsection{Durability of Particleboard Against to Subterranean Termite Attack}

In fact, the material containing cellulose will be the main feeding for subterranean termites. The resistance of JFH particleboard against subterranean termites was measured using weight loss, mortality, antifeedant and feeding rate parameter. Over all, the treated specimens had lower weight loss compared to untreated specimens. Hot water treatment results the lowest weight loss value $(12.3 \%)$ and this loss decrease approximately to $51 \%$ to control. The classification of wood resistance to subterranean termites according to SNI 01.7207-2006 showed that the specimen treated in hot water and acetic acid are classified into weak resistance (class IV) while cold water and untreated specimens are classified into very weak resistance (class V). Hot water treatment is selected as the best treatment to increase the board durability to termite attack. This treatment was predicted able to remove the starch content as one the extractive substances dissolved in hot water. Starch includes as one of termite feed sources besides cellulose. Kanai et al. (1982) tested amylosa (polysaccharides) as feed source for termite in which at the end of the experiment during 8 weeks, $72 \%$ termites still survived. with the similar result demonstrated on utilization of wood meal as feed source found about $75 \%$ termite survival. Termite weight decreased gradually up to $85 \%$ of the initial weight during eight weeks. These results was inline with utilization of suchrose (disaccharides), glucose and fructose (monosaccharides). These results strongly suggest that termites can utilize these compounds as feed.

The JFH particleboards had low durability because JFH was classified as nondurable materials. According to Fig. 2, extractive content of JFH in $1 \% \mathrm{NaOH}-$ extraction is $35 \%$. The high extractive content indicates the material is not durable (Tsoumis 1991). JFH has high susceptibility on degradation by deterioration organism and environment condition (oxidation by temperature and humidity). The durability of particleboard against deteriorating biological agents is affected by the fiber properties, whereas more durable fiber will have better resistances against deteriorating organisms such as fungi and termites (Kose et al., 2011).

Termites mortality and antifeedant value in particleboard in immersing treatments (cold water, hot water, and acetic acid solution) are higher than in control. Immersing treatment in hot water produces the highest mortality and antifeedant value $87.4 \%$ (Fig. 9) and $34.2 \%$ (Fig. 10), respectively. Hot water treatment increases the mortality approximately $17 \%$ compared to untreated ones (Fig. 9).

Based on antifeedant classification (Sornnuwat, 1995), immersing treatment in hot water results moderately strong resistance, while other treatments include in weak resistance. Based on the feeding rate value (Fig. 10), immersing treatment in hot water produces the lowest value (45.3 $\mu \mathrm{g} /$ termite/day). This value decrease approximately $56 \%$ compared to untreated samples.

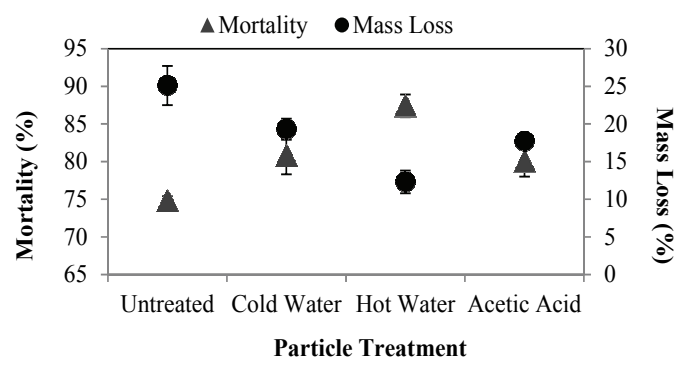

Fig. 9. Mortality and mass loss of particleboard. 


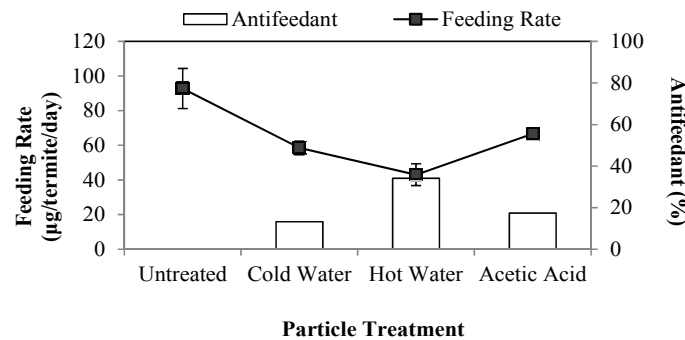

Fig. 10. Antifeedant and feeding rate of particleboard.

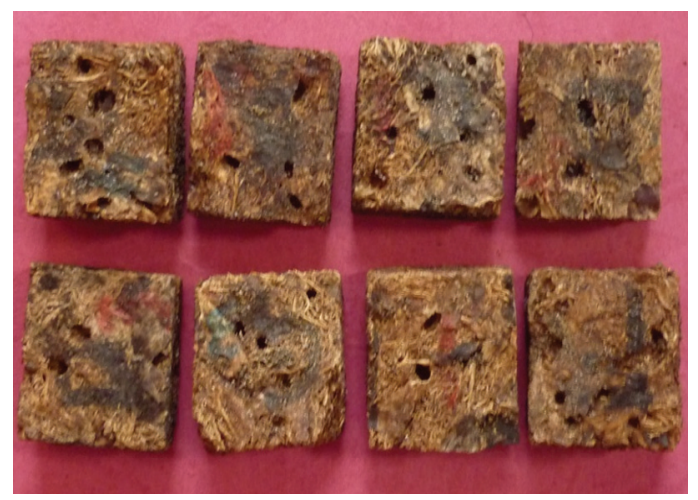

Fig. 11. Subterranean termite attack.

According to Fig. 11, termite attack on specimens was mostly initiated from surface the particleboard by making holes and going down to the inside of the board. It will soften surface board to make it more susceptible to be feed. However, these results are in contrary with the previous research on sisal particleboard. Termite attack is initiated from middle part of boards because the surface layer was overlaid by veneer having higher density compared to the core layer (Syamani et al., 2011). Particle treatment provides significant difference to weight loss, mortality and feeding rate. All pretreatments reveal significant difference compared to untreated sample. These same results also occur in mortality and feeding rate value. The best treatment is found in the treatment of immerssion in hot water considering the weight loss, the highest mortality rate, the lowest feeding rate as much as $12.30 \%, 87.40 \%$, and $45.30 \%$, respectively. It can be concluded that the immerssion in hot water was the best treatment to produce the most durable JFH particleboard againts to subterranean termites.

\section{CONCLUSION}

Particle pre-treatment is able to reduce the $\mathrm{pH}$ compared to untreated samples. This decreasing $\mathrm{pH}$ results better physical and mechanical properties of JFH particleboard using urea formaldehyde resin. The improvement of board quality proves that UF resin performs well in acid condition. Particle immersing in $1 \%$ acetic acid solution results the best physicalmechanical properties. Pre-treatment has improves particleboard durability to subterranean termite attack. According to mass loss, mortality, antifeedant value and feeding rate, hot water treatment provides the best results. JFH particleboard is classified into weak and very weak resistance. It is suggested for improving the durability properties of particleboard could be done using some preservatives and acetic anhydride.

\section{REFERENCES}

Colak, S., olakǒglu, G.C. 2006. Effects of Wood Species and Adhesive Types on The Amount of Volatile Acetic Acid of Plywood by Using DesiccatorMethod. Holz als Roh- und Werkstoff 64: 513-514. Febrianto, F., Royama, L.I., Hidayat, W., Bakar, E.S., Kwon, J.H., Kim, N.H. 2009. Development of Oriented Strand Board from Acacia Wood (Acacia mangium Willd): Effect of Pretreatment of Strand and Adhesive Content on the Physical and Mechanical Properties of OSB. Journal of the Korean Wood Science \& Technology 37(2): 121127

Freeman, H.G. 1959. Relation Between Physical and Chemical Properties of Wood and Adhesion. Forest Product Journal 9(12): 451-458. 
Apri Heri Iswanto $\cdot$ Fauzi Febrianto $\cdot$ Yusuf Sudo Hadi $\cdot$ Surdiding Ruhendi $\cdot$ Dede Hermawan $\cdot$ Widya Fatriasari

Harmsen, P.F.H., Huijgen, W.J.J., Lopez, L.M.B., Bakker, R.R.C. 2010. Literature Review of Physical and Chemical Pre-treatment Processes for Lignocellulosic Biomass. Project Report. Wageningen, Germany.

Hadi, Y.S. 1991. Pengaruh Perendaman Panas dan Asetilasi selumbar Terhadap Sifat Papan Partikel. [Dissertation]. Bogor: Graduated Program, Bogor Agricultural University.

He, G., Riedl, B. 2004. Curing Kinetics of Phenol Formaldehyde Resin and Wood-Resin Interactions In The Presence of Wood Substrates. Wood Science and Technology 38: 69-81.

Indonesian National Standard. 2006. Wood and Wood Products Resistance Test to Wood Destroying Organism. Indonesian National Standard Bureau, Jakarta, Indonesia.

Iswanto, A.H., Simarmata, J., Fatriasari, W., Azhar, I., Sucipto, S., Hartono, R. 2017. Physical and Mechanical Properties of Three- Layer Particleboards Bonded With UF and UMF Adhesives. Journal of the Korean Wood Science \& Technoloy 45(6): 787-796.

Iswanto, A.H., Febrianto F., Wahyudi, I., Hwang, W.J., Lee, S.H., Kwon, J.H., Kwon, S.M., Kim, N.H., Kondo, T. 2010. Effect of Pre-treatment Techniques on Physical, Mechanical and Durability Properties of Oriented Strand Board Made from Sentang Wood (Melia excelsa Jack). Journal of the Faculty Agriculture, Kyushu University 55(2): 371-377.

Jasni., Sulastiningsih, I.M. 2004. The Resistance of Treated Rubberwood Particleboard to The Drywood Termite (Cryptotermes cynocephalus Light). J Penelitian Hasil Hutan 22(2): 69-74.

Johns, W.E., Niazi, K.A. 1980. Effect of $\mathrm{pH}$ and Buffering Capacity of Wood on The Gelation of Urea Formaldehyde Resin. Wood and Fiber Science 12(4): 256-263.

Kamal, I., Poh, K.M., Eng, T.Y., Ren, X.J, Ashaari,
Z. 2010. Buffering Capacity of Fast Growing Species and Curing Time of UF Resin Modified With Zinc Borate and Monoammonium Phospate. American Journal of Applied Science 7(8): 10791082.

Kanai, K., Azuma, J.I., Nishimoto, K. 1982. Studies on Digestive System of Termites: I. Digestion of Carbohydrates by Termite Coptotermes formosanus Shiraki. J. Wood Research 68: 47-57

Kelly, M.W. 1977. Critical Literature Review of Relationship Between Processing Parameter and Physical Properties of particleboard. General Technical Report FPL-10. U.S. Department of Agriculture Forest Service and Forest Products Laboratory University of Wisconsin.

Kose, C., Terzi, E., Buyuksari, U., Avei, E., Ayrilmis, N., Kartal, S.N., Imamura, Y. 2011. Particleboard and MDF Panels Made From A Mixture of Wood and Pinecones: Resistance to Decay Fungi and Termites Under Laboratory Conditions. BioResources 6(2): 2045 2054.

Krilov, A., Lasander, W.H. 1988. Acidity of Heartwood and Sapwood in Some Eucalyptus Species. Holzforschung 42(4): 253-258.

Langum, C.E. 2007. Characterization of Pacific Northwest Softwoods For Wood Composites Production. [Thesis]. Washington State University, USA.

Malanit, P., Barbu, M.C., Fruhwald A. 2009. The Gluability and Bonding Quality of an Asian Bamboo (Dendrocalamus asper) for The Production of Composite Lumber. Journal of Tropical Forest Science 21(4): 361-368.

Maulana, S., Busyra, I., Fatrawana, A., Hidayat, W., Sari, R.K., Sumardi, I., Wistara, I.N.J., Lee, S.H., Kim, N.H., Febrianto, F. 2017. Effects of Steam Treatment on Physical and Mechanical Properties of Bamboo Oriented Strand Board. Journal of the Korean Wood Science \& Technology 45(6): 872882 . 
Pan, Z., Zheng, Yi., Zhang, R., Jenkins, B.M. 2007. Physical Properties of Thin Particleboard Made From Saline Eucalyptus. Industrial Crops and products 26: 185-194.

Paridah, M.T., Chin, A.M.E., Zaidon, A. 2001. Bonding Properties of Azadirachta excelsa. Journal of Tropical Forest Products 7: 161-171.

Park, B.D., Kim, Y.S., Rield, B. 2001. Effect of woodfiber characteristics on medium density fiberboard (MDF) performance. Journal of the Korean Wood Science and Technology 29: 27-35.

Podgorski, L., Chevet, B., Onic, L., Merlin, A. 2000. Modification of Wood Wettability by Plasma and Corona Treatments. International Journal of Adhesion and Adhesives 20: 103 111.

Sernek, M. 2002. Comparative Analysis of Inactivated Wood Surface. [Dissertation]. Virginia Polytechnic Institute and State University. Blacksburg, Virginia. Sornnuwat, Y., Vongkaluang, C., Yoshimura, T., Tsunoda, K., Takahashi, M. 1995. Tunneling of Subterranean Termites, Coptotermes Gestroi Wasmann and Coptotermes Formosanus Shiraki, Into Gravel Physical Barriers. Japanese Journal of Environmental Entomology and Zoology 7(1): 13-19.

Sudradjat, R., Tresnawati, D., Setiawan, D. 2005. Manufacture of Activated Charcoal from Jatropha Seed Shell. Jurnal Penelitian Hasil Hutan 23(2): 143-162
Sujadi. 1985. Penentuan Struktur Senyawa Organik. Jakarta (ID): Ghalia Indonesia Pr.

Syamani, F.A., Massijaya, M.Y., Subiyanto, B. 2011. Termite Resistant Properties of Sisal Board. Insects 2(4): 462-468.

[TAPPI] Technical Association of Pulp and Paper Industry T 4 os-59. 1959. One Percent Caustic Soda Solubility of Wood. Atlanta (US): TAPPI Pr.

TAPPI] Technical Association of Pulp and Paper Industry T 1 os-50. 1950. Water Solubility of Wood. Atlanta (US): TAPPI Pr.

Tascioglu, C., Yoshimura, T., Tsunoda, K. 2013. Biological Decay and Termite Resistanceof PostTreated Wood-Based Composites Under Protected Above-Ground Condition: A Preliminary Study after 36 Months of Exposure. BioResources 8(1): 833-843.

Tsoumis, G. 1991. Science and Technology of Wood: Structure, Properties, Utilization. Van Nostrand Reinhold, New York.

Xing, C., Zhang, S.Y., Deng, J. 2004. Effect of Wood Acidity and Catalyst on UF Resin Gel Time. Holzforschung 58: 408-412.

Zanetti, M., Pizzi, A. 2003. Upgrading of MUF Resins by Buffering Additives. Part 2: Hexamine Sulphate Mechanisms and Alternate Buffers. Journal of Applied Polymer Science 90: 215-226. 